\title{
The oldest new woodland on earth: Recognising, mapping, naming and narrating the Great Western Woodlands'
}

ALEXANDRA VLACHOS

School of History, The Australian

National University, Australia

ANDREA GAYNOR

School of Humanities, University of Western Australia, Australia

\section{Abstract}

The Great Western Woodlands (GWW) cover an area of $160,000 \mathrm{~km}^{2}$ of largely intact semi-arid woodland in inland south-western Australia. The highly biodiverse GWW is a large-scale ecosystem and a refuge for native species endangered elsewhere, but faces many challenges, including poor fire management, mining and mining exploration impacts, proposed clearing for agriculture, introduced species and climate change. This paper traces the way in which stories about the region have powerfully shaped different groups' dealings with it. In Western Australia, settler society's long-standing focus on the agricultural zone of the Wheatbelt and the mineral wealth of the goldfields as 'productive' landscapes produced a dominant narrative about conquering nature, physical labour and economic wealth that marginalised the ecologies and First Peoples of the GWW. More recently, a network of local settler and Indigenous people, NGOs, scientists and conservationists have begun to produce a new narrative with the cultural and natural values of the woodland at its heart, as a foundation for better understanding, managing and protecting the GWW. Reflecting on the historical framing of a particular region reveals the important cultural-ecological work performed by regional narratives.

Keywords: narrative, Western Australia, Mediterranean-climate woodlands, mining, Indigenous people

\footnotetext{
1 Acknowledgements: This research was greatly assisted by the generous sharing of time, ideas and resources by Keith Bradby, Amanda Keesing, Ian Hereford, Steven Hopper, Simon Judd, Les Schultz, Tjubriin Valma Wicker-Schultz, Peter Price, Suzanne Prober and Brian Moyle. The research was supported by the Swiss National Science Foundation postdoc mobility fellowship (grant number 178525), enabling Alexandra Vlachos to undertake extended stays at the University of Western Australia and The Australian National University in 2018 and 2019.
} 
Western Australian woodlands have been so badly recognised and supported that in the 21 st century it is still possible to 'discover' vast, relatively unknown areas, which have similar global importance to places like the Great Barrier Reef. ${ }^{2}$

\section{Introduction}

In 2010, a vast area in southern Western Australia was named the 'Great Western Woodlands' (GWW) and claimed to be the largest Mediterranean-climate woodland remaining on Earth. ${ }^{3}$ Covering almost $160,000 \mathrm{~km}^{2}$, the area stretches from the farmlands that break its continuity to the east and south, to the pastoral fields of the mulga country, the inland deserts to the north, and the Nullarbor Plain in the east. For an area most Australians - if they were to think of it at all-would imagine to be a desert of sparse mulga, saltbush, sand and rock, the area is surprisingly wooded. From delicate mallees to stately salmon gums, the region is home to over 160 species of eucalypt. Unlike anywhere else in the world, large trees form woodland on an annual rainfall often less than $250 \mathrm{~mm}$. The GWW's history is a narrative tapestry of local history, Aboriginal heritage and settler identity stories. Most recently, the area provides an example of a process of giving new shape and meaning to an ecologically and socially diverse area through naming and mapping. The new narrative of the GWW has provided an umbrella under which diverse interests can meet, and although its creation was not without tensions, it has worked to open up the area to new stories, empowering science and conservation in the region while facilitating — or at least not impeding-Indigenous ownership and management.

The GWW has been shaped by millennia of natural processes, as well as the management practices of Indigenous people and, more recently, settlers. These practices are produced and made meaningful through stories. Environmental historians have long been alert to the power of narrative to shape worlds. As Bill Cronon put it in his 1992 navigation of the post-structuralist challenge to history: 'narratives remain our chief moral compass in the world. Because we use them to motivate and explain our actions, the stories we tell change the way we act in the world.' ${ }^{\prime}$ Thomas King arrives at a similar conclusion from a native studies perspective: 'Want a different ethic? Tell a different story'. ${ }^{5}$ More recently, Tom Griffiths has described the story as

\footnotetext{
2 Keith Bradby: 'Putting woodlands in their place', in Temperate Woodland Conservation and Management, ed. David Lindenmayer, Andrew Bennett and Richard Hobbs (Collingwood: CSIRO Publishing 2010), 36.

3 Western Australian Department of Environment and Conservation, A Biodiversity and Cultural Conservation Strategy for the Great Western Woodlands (Perth: WA Department of Environment and Conservation, 2010), 6.

4 William Cronon, 'A place for stories: Nature, history, and narrative', Journal of American History 78, no. 4 (1992): 1375, doi.org/10.2307/2079346.

5 Thomas King, The Truth About Stories (Minneapolis: University of Minnesota Press, 2003), 164.
} 
a piece of disciplined magic, of highly refined science. It is the most powerful educational tool we possess; it is learning distilled in a common language. It is also a privileged carrier of truth, a way of allowing for multiplicity and complexity at the same time as guaranteeing memorability. ${ }^{6}$

But as King reminds us, not all stories are equal. ${ }^{7}$ Some of the most enduring and powerful stories we tell are historical: stories about how things came to bewhy they are as they are today-and that accord certain privileges or burdens to particular social groups. Germane to our inquiry are Anssi Paasi's observations about the creation of regional consciousness, in which the past-as well as the futureoften provide common frames of reference. ${ }^{8}$

Narratives - individual and collective-express our values and shape our behaviour, and stories - old and new-therefore shape and change the way we live with nature. ${ }^{9}$ As Raul Lejano, Mrill Ingram and Helen Ingram show, stories play a critical role in the formation of social networks that arise around issues of ecological and resource management: environmental (and indeed extractive) communities 'story' themselves into narrative networks. These narrative networks in turn become responsible for how they 'understand their environmental connections, whether it is to defend or to exploit'. ${ }^{10}$ While it is important to attend to a range of factorseconomic and policy among them-to explain how and why communities emerge in environmental relation, close attention to stories allows, as Patrick Bixler puts it: 'a more nuanced account of the interconnections and interactions between the scientific and the social, the economic and the political'. ${ }^{11}$

6 Tom Griffiths, 'The humanities and an environmentally sustainable Australia', Australian Humanities Review 43 (2007), australianhumanitiesreview.org/2007/03/01/the-humanities-and-an-environmentally-sustainable-australia, accessed 6 June 2021.

7 King, The Truth About Stories, 10.

8 Anssi Paasi, 'The institutionalization of regions: A theoretical framework for understanding the emergence of regions and the constitution of regional identity', Fennia: International Journal of Geography 164, no. 1 (1986): 105-46, doi.org/10.11143/9052.

9 There is no universal distinction of the terms 'story' and 'narrative'. The two terms are often used interchangeably. Narrative theory offers the useful distinction of narrative being the 'overall idea' of individual stories. A narrative can thus include stories and memories, but it is ongoing, it can be disputed, changed or told differently. Stories usually have a beginning and an end, and follow a particular plot. The plot tells how; the stories tell what, who and where. In contrast, narratives describe a bigger idea or ideology, often comprised of a set of stories, facts and memories. They tell why and offer interpretation(s) of a set of stories. Theorists of narrative psychology, such as James Wertsch, have argued that narratives follow templates of collective stories, which shape shared understandings and memories of events and outcomes. In the context of this paper, stories and memories are individual accounts of events and histories which add up to dominant ('master-narratives') or alternative narratives about place, each shaping environmental behaviour. Raul Lejano et al., 'Environmental action in the Anthropocene: The power of narrative networks', Journal of Environmental Policy and Planning 21, no. 5 (2015):1-16, doi.org/10.1080/1523 908X.2015.1113513; see James V. Wertsch, Voices of Collective Remembering (New York: Cambridge University Press, 2002), doi.org/10.1017/CBO9780511613715; and James V. Wertsch, 'Collective memory and narrative templates', Social Research 75 (2008): 133-56.

10 Raul Lejano et al., The Power of Narrative in Environmental Networks (Cambridge, MA, and London: MIT Press, 2013), 2.

11 R. P. Bixler, 'The political ecology of local environmental narratives: Power, knowledge, and mountain Caribou conservation', Journal of Political Ecology 20 (2013): 276, doi.org/10.2458/v20i1.21749. 
Until the early twenty-first century, the 'Great Western Woodlands' as a distinct region did not exist and as such it had no story. It could not be found on any map and was without borders or a name. Even today, its story is still not widely known. For example, the GWW is missing in Australian Geographic's 2017 compilation of the nation's forests (which includes woodlands, such as the Yellow Box Woodland of South Australia). ${ }^{12}$ The GWW is remote from major settlements, but the same is true for the Nullarbor Plain, the Kimberley and Kakadu, all of which have well-known stories. The relatively low profile of the GWW can be accounted for partly by its relatively recent genesis, and partly by the dominant narrative of the 'goldfields' concealing the presence of trees in a place where mining and pastoralism fuelled the dreams of a young settler colony and then state. Historical descriptions of places within the GWW also follow concentrations of settler activity in a sparsely populated area. They are therefore geographically fragmented and heavily focused on the towns, mines and pastoral stations. Paasi proposes that formation of regional identity begins with mapping of boundaries, but within this region, much of the settler population was transient and there were few substantial settlements. These sat isolated within much larger formal land divisions, created for statistical and electoral purposes, so with the exception of the sharp agricultural boundary to the south-west, discussed below, regional identity cohered not so much around territorial shape, but conceptual or symbolic shape-that is, narrative. ${ }^{13}$ Historical stories of these places generally form part of a human-centred metanarrative, in which white men pit themselves and their technology against unruly and uncompromising nature, building the nation-and national character-in the process. This metanarrative marginalised the presence, let alone agency, of diverse others in the region.

Since the advent of social history, historians have 'storied' settler women and migrants from beyond the British Isles into the region, conventionally within a pioneering—and often urban-narrative frame. ${ }^{14}$ Aboriginal people, too, increasingly appear within settler historical stories. ${ }^{15}$ But in the collective memory

12 Shanon Verhagen, 'Getting to know Australia's diverse forests', Australian Geographic, 21 March 2017, www. australiangeographic.com.au/topics/science-environment/2017/03/australias-diverse-forests, accessed 6 June 2012.

13 For an overview of the process of regional identity formation, see Paasi, 'The institutionalization of regions', $122-3$.

14 See for example Rica Erickson, The Dempsters (Nedlands: University of Western Australia Press 1978); Norma King, The Daughters of Midas (Perth: Hesperian Press, 1988); Ian Templeman and Bernadette McDonald, The Fields: The Kalgoorlie and Coolgardie Goldfields, 1892-1912 (Fremantle: Fremantle Arts Centre Press, 1988); Martin Webb and Audrey Webb, Golden Destiny: The Centenary History of Kalgoorlie Boulder and the Eastern Goldfields of Western Australia (Kalgoorlie: City of Kalgoorlie-Boulder, 1993); Vera Whittington, Gold and Typhoid: Two Fevers (Nedlands: University of Western Australia Press, 1988). Works telling stories beyond the pioneering narrative include Bill Bunbury, Timber for Gold: Life on the Goldfields Woodlines, 1899-1965 (Fremantle: Fremantle Arts Centre Press, 1997); Philip Goldswain and William Taylor, An Everyday Transience: The Urban Imaginary of Goldfields Photographer John Joseph Dwyer (Perth: UWA Publishing, 2010); Sarah Gregson, "II all started on the mines”? The 1934 Kalgoorlie race riots revisited', Labour History 80 (2001): 21-40, doi.org/10.2307/27516768.

15 See for example Criena Fitzgerald and National Foundation for Australian Women, Karlkurla Gold: A History of the Women of Kalgoorlie-Boulder, Australian Women's Archives Project, December 2012, www.womenaustralia. info/exhib/wikb/introduction.html, accessed 6 June 2021. 
of a society that relied on masculine and 'productive' dominium terrae by mining, grazing stock or clearing the bush for agriculture, there was room for only timber, not trees. Woodland counter-narratives are hidden within the archival records, in oral traditions and embodied in place. Considering them reveals the GWW region as a complex, dynamic and surprisingly historical living landscape, unsettling the dominant settler narratives of gold and wheat, and supporting the new story of an old and complex woodland.

This article presents a historiography of the new and emerging GWW narrative in the context of the previously dominant narrative. We trace the emergence of enduring mainstream stories about the GWW region, centred around settler forms of economic development as the wellspring of progress, and highlighting the role of particular actors while eliding others. These stories have enduringly constructed the woodlands as a field for white, masculine endeavour, to be made productive through hard work (and occasionally good luck) as well as infrastructural gigantism. This narrative has defined the settler community's orientation to the region and their pursuit of both livelihood and profit within it, as well as legitimating social and environmental exploitation on a grand scale. We then trace some of the developments enabled by the dominant narrative, before turning to the early twenty-first century, when a loose coalition of environmentalists, scientists and Indigenous people began to re-narrate the place as 'Great Western Woodlands' in an attempt to give the former 'bush beyond the fence' new meaning through the power of narrative, and integrate it into a larger connectivity conservation vision for Australia's southwestern corner. In order to establish it within settler society as a coherent region, the GWW had to become a named place on a map. This provided a new perspective on the region and an opportunity to value it as a woodland anew. This new designation is becoming better known in some contexts, but the older pioneering narrative is still dominant in others. Like all narratives, the GWW draws attention to some aspects of the region while eliding others. Its use of 'Great' risks invoking the kind of triumphalism that characterised the older narrative, and its use of 'woodland' elides the diversity of vegetation found within the region. Furthermore, while the GWW narrative is more accommodating of Aboriginal presence and stories, it remains a non-Indigenous frame. Still, we argue that in spite of the shortcomings of its title, the new narrative accommodates diversity and enables multiple-and more sustainable - ways of seeing and relating to this old land.

\section{Deep time and Dreamtime}

The area mapped out as the GWW after the turn of the millennium is vast and diverse, encompassing large parts of the Country of Indigenous Ngadju, Kalaamaya and Noongar people; Australia's largest outback city, Kalgoorlie-Boulder; the towns of Norseman and Coolgardie; seven different shires; private land (1 per cent); 
pastoral leases (20 per cent); conservation reserves (14 per cent); four national parks ( 2 per cent) and more than 300 active mining leases. ${ }^{16}$ While approximately 60 per cent of the GWW remained Unallocated Crown Land in 2010, the Federal Court of Australia confirmed Ngadju exclusive and non-exclusive native title within (and beyond) large parts of the GWW in 2014 and 2017 (see Figure 1). The Ngadju Determination covers 40 per cent of the total area of the GWW, reducing Unallocated Crown Land to less than 20 per cent, while the Esperance Tjaltjraak non-exclusive title and the WA Mirning People exclusive and non-exclusive title in the south further reduced that amount to 14 per cent.

The GWW is one of the world's few large-scale functioning ecosystems, retaining considerable ecological integrity over a vast area. It is thus a global rarity as well as an outstanding ecological treasure. Although dominated by woodland, it includes significant areas of mallee (noting that areas of tall mallee eucalypts also qualify as woodland) and shrubland zones, as well as some smaller areas of grassland (see Figure 2). Its biodiversity covers 20 per cent of all Australian plant species in an area of less than 2 per cent of the country, ${ }^{17}$ and it supports 15 priority ecological communities. ${ }^{18}$ The spring wildflowers have long impressed and delighted newcomers. In 1896, for example, the geographer A. J. Vogan, exploring the north-eastern edge of what would become the GWW, exclaimed: 'How prolific is this ruddy, ironstained soil ... of wildflowers! White, yellow, and red daisy-like everlasting flowers carpet the ground. Acacias and baronias make the soft air heavy with sweet odour'. The trees figured much less prominently in such narratives, being dissolved in what settlers simply referred to as 'the bush' or 'scrub'. Vogan also waxed lyrical about the rock formations, giving the name 'butterfly cliffs' to a breakaway of the most 'marvellously coloured piece of iron-stained, kaolinised, archaen rock' he had ever seen. ${ }^{19}$

16 Alexander Watson et al., The Extraordinary Nature of the Great Western Woodlands (Perth: The Wilderness Society of WA, 2008); Western Australian Department of Environment and Conservation, A Biodiversity and Cultural Conservation Strategy, 6.

17 Denis Saunders and Stephen Hopper, 'The woodlands declaration. An open letter to Western Australian Premier Colin Barnett and Western Australian Environment Minister Donna Faragher', 20 January 2010, www. wilderness.org.au/images/resources/Wilderness-Society-REPORT-Science-statement-of-support.pdf.

18 These are ecological communities that are either poorly known, or rare but not clearly and imminently threatened. Western Australian Department of Biodiversity, Conservation and Attractions, 'Threatened ecological communities', www.dpaw.wa.gov.au/plants-and-animals/threatened-species-and-communities/wa-s-threatenedecological-communities, accessed 6 June 2021.

19 A. J. Vogan, 'Through Aurumalia', Coolgardie Pioneer, 3 October 1896, 4. 


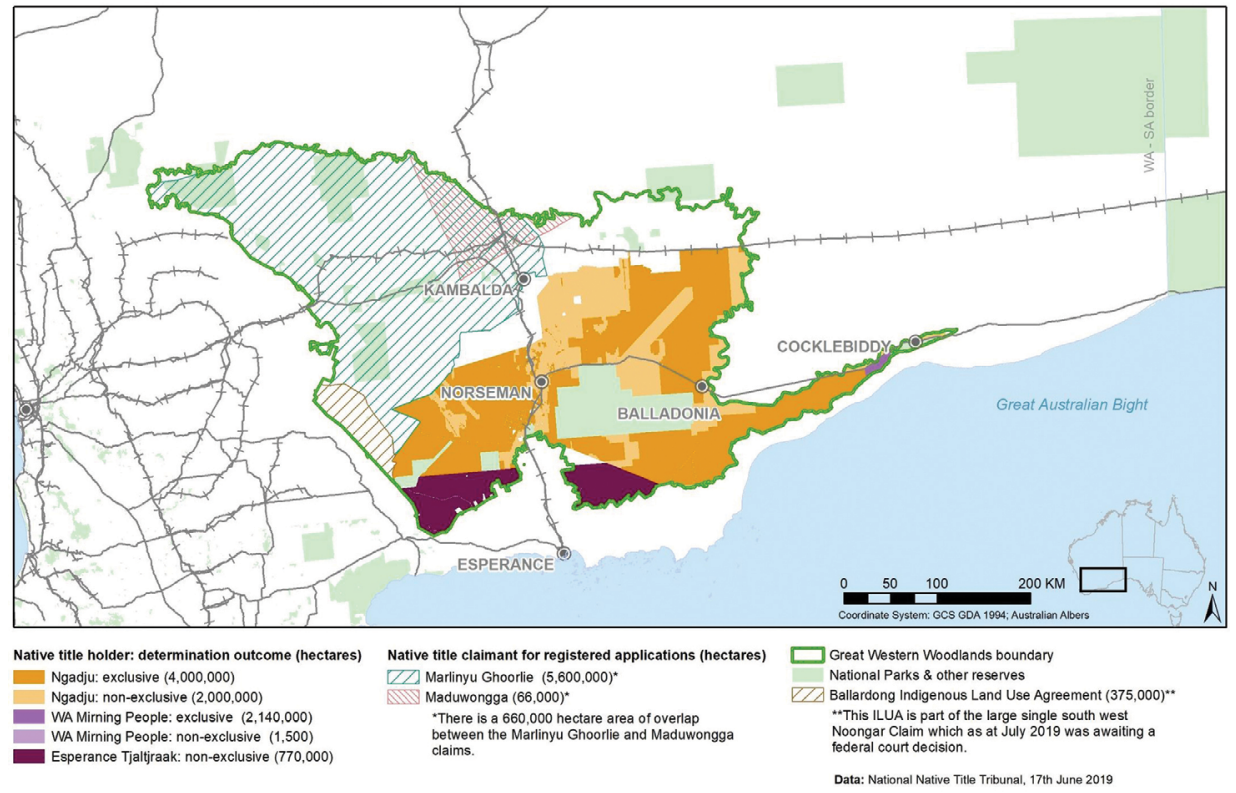

Figure 1: Native Title within the GWW as of June 2019.

Source: Centre for Conservation Geography.

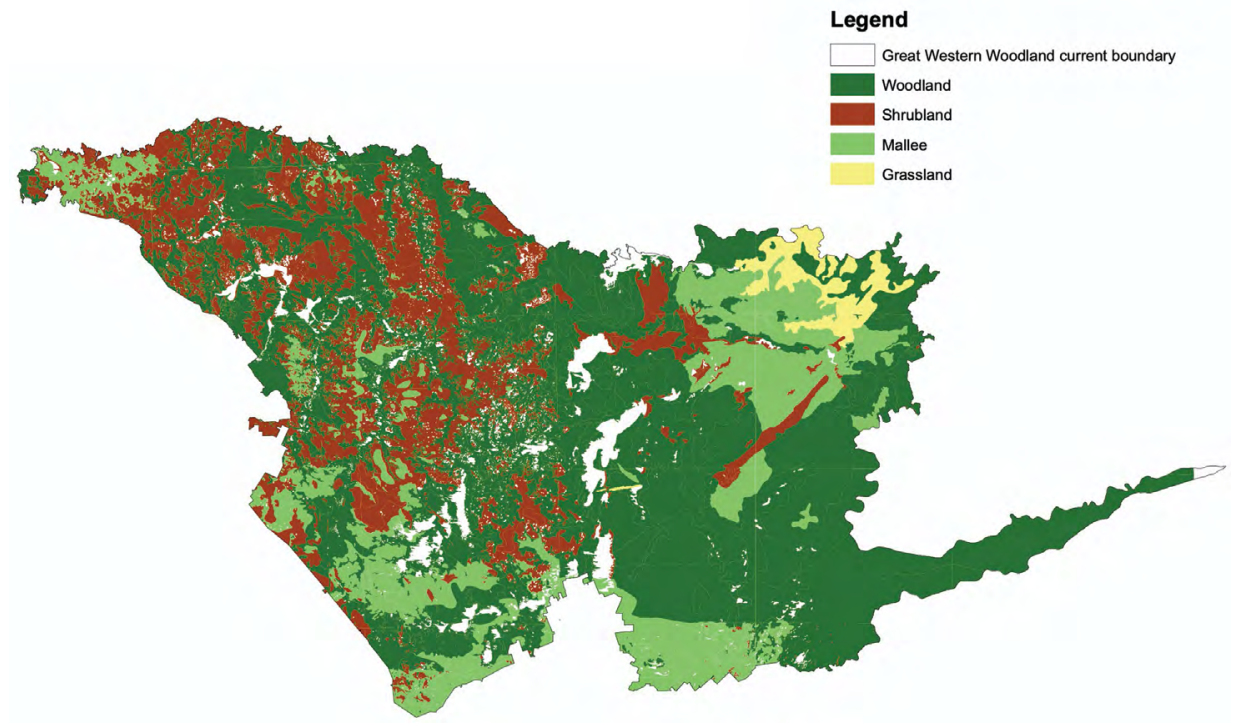

Figure 2: Great Western Woodland basic vegetation types.

Source: Created by Amanda Keesing using Simon Judd's shapefiles derived from J. S. Beard's vegetation data. 
The GWW's environmental qualities have their origins in deep time. The soils and landforms of the GWW - the bones of the place-are some of the most ancient in the world, straddling the Yilgarn Craton and other Precambrian complexes. The granite-gneiss metamorphic terrain of the Yilgarn Craton is around 2.8 billion years old, while its granite-greenstone terrains are between 2.6 and 3.3 billion years old. The latter encompass the Southern Cross area and the north-eastern goldfields, which host Australia's largest lode gold deposits along the Archaean NorsemanWiluna Greenstone Belt. The granite domes characteristic of the southern interior are likewise of Archaean origin. These features stand out in the otherwise low-relief, eroded landscapes of the GWW, which have been undisturbed by inundation or glaciation for around 250 million years. The age and complexity of the region's soils, along with climatic changes, led to high levels of speciation, accounting for the extraordinary biodiversity of the region today. ${ }^{20}$ The subdued landscape rarely drains to the sea, so airborne salt over millions of years has accumulated in the groundwater, soils and chains of salt lakes.

There are alternative stories of how this landscape evolved. While there is no public record of Ngadju, Kalaamaya or Noongar creation stories for the GWW, the Ngadju People provided significant evidence relating to Dreaming sites and stories-about the creation of the landscape and its features by ancestral beings - in the Native Title determination process that concluded in 2012. ${ }^{21}$ Dreamtime refers to the present as much as to the past and is narrated into the living landscape. It is a map of Country, revealing where to go, camp and find water-and where to avoid. As such, both Dreamtime and deep time are accessible through the physical landscape, by those with the requisite knowledge. Deep time is the deep past, but it has a physical place in the present-and connects the past to the present by narrative. The Ngadju People move comfortably in the 'spacetime' of the dreaming, where the rocks, hills, waterholes and trees of today's GWW tell the stories of the past and figure as signposts on walking trails through Country. The GWW is home to numerous songlines: the songs and stories of specific places that pass on embodied knowledge of the land to following generations. ${ }^{22}$ Songlines connected Aboriginal people from the south coast to the desert inland. ${ }^{23}$ They cared for Country while travelling through it;

\footnotetext{
20 Watson, The Extraordinary Nature, 35.

21 See Graham on behalf of the Ngadju People v State of Western Australia [2012], Federal Court of Australia 1455 (21 December 2012), www8.austlii.edu.au/cgi-bin/viewdoc/au/cases/cth/FCA/2012/1455.html, accessed 6 June 2021.

22 Aunty Carrol Petterson the Dreaming Trail Map by Noel Nannup, 24 April 2018, www.youtube.com/ watch?v=wu427QEBfuc, accessed 1 April 2019; 'Singing the country to life' ABC News, 4 July 2016, www.abc.net. au/news/2016-07-04/naidoc-week-indigenous-songlines/7557654, accessed 6 June 2021.

23 Myles Mitchell, 'The Esperance Nyungars, at the frontier: An archaeological investigation of mobility, aggregation and identity in late-holocene Aboriginal society, Western Australia', (PhD diss., The Australian National University, 2016), 67.
} 
walking was simultaneously an economic, environmental, cultural and social act. In contemporary times, Ngadju elders such as James Schultz from Norseman strive to connect Dreamtime with another layer of time: the (post-)colonial present. ${ }^{24}$

Aboriginal people have been living, managing and caring for what is now known as the GWW for at least 45,000 years. ${ }^{25}$ The dreaming, oral traditions, extensive songlines and sacred sites, backed by archaeology and the visible impacts of Aboriginal land management and burning practices, provide evidence of a longstanding and intimate knowledge of the country and its ecology. The colonial history of dispossession, murder and displacement is responsible for the loss of some of that knowledge. ${ }^{26}$ As in other parts of the country, Aboriginal people within the woodland were killed, relocated, fenced out or co-opted. Many took work on stations or white settlements, where they generously provided the newcomers with knowledge and skills. The histories of Fraser Range, Noondoonia, Nanambinia and Balladonia stations are thus closely entangled with Ngadju and Noongar labour and knowledge. Interracial marriages were common, and resulted in strong ties and shared family trees. ${ }^{27}$

The main drivers of settler incursions into the woodland, hundreds of kilometres east of Perth, were pastoral expansion and mining. When the first pastoralists arrived in the woodland in their search for suitable land, they knew Aboriginal people were there, but did not see themselves as exploring a modified and managed landscape. They did not know the country's story and were unable to read its narrative map, so heavily depended on Indigenous knowledge for water and guidance. Accompanied by his Noongar guide in the mid-1860s, Charles Hunt relied on Kaalamaya and Malapa Ngadju knowledge to find the water sources that would sustain a growing stream of travellers to the goldfields. In a collective act of erasure of Aboriginal presence and knowledge, these became known as 'Hunt's wells'. Hunt noted that a group of Kaprun people ${ }^{28}$ he met near today's Southern Cross 'at all times carry fire sticks before them'. ${ }^{29}$ Yet he failed to understand the fire management practices of the woodland people and was not aware that what he described as 'good patches of grass' were actually Aboriginal hunting sites that had been burned to attract grazing

\footnotetext{
24 Les Schultz, personal communication with Alexandra Vlachos, 20 October 2018.

25 Moya Smith, Aboriginal Sites in Ngadju Country (East Perth: Ngadju Bugarla Mirning Wamu Wamu Aboriginal Corporation, 1994).

26 Graham v State of Western Australia.

27 Peter Gifford, Black and White and in between: Arthur Dimer and the Nullarbor (Perth: Hesperian Press, 2002); Erickson, The Dempsters.

28 The Kaprun Kamalaaya are a tribe east of Ngadju territory. Their territory once covered a large area around Southern Cross in the Yilgarn (north-western GWW). Most Kaprun people were taken away from country and placed into missions or reserves and Brian Champion is the only remaining fluent speaker of the Kaprun language. He spent most of his childhood in the Norseman mission and lives in Kalgoorlie today.

29 Charles Edward Dempster and/or Andrew Dempster, 'Journal of an exploring expedition to the eastward of Northam', Inquirer and Commercial News, 11 September 1861, 2.
} 
animals. The Ngadju burnt selectively and maintained fire-free woodland areas; it is only since the new narrative of the GWW attracted more Western science that the great age of unburnt old-growth woodland has become better recognised. ${ }^{30}$

The 1890s saw the first major gold rushes in the Yilgarn and Kalgoorlie-Coolgardie area. The prospect of gold lured seekers from across Australia into a place they experienced as remote and inhospitable. In the early years of the twentieth century, the GWW became the scene of-and through its timber enabled-constructions that were some of the largest in the world at the time: the Goldfields Water Supply Scheme and Rabbit Proof Fence, as well as a railway that provided an economic and social lifeline to Perth. At this time, the dominant narrative shaping settler understanding of the region was of an arid and hostile land that could be put to good use through individual pluck and courage on the one hand, and massive state-sponsored infrastructure projects on the other.

Vast numbers of trees were felled, initially fuelling water condensers to sustain growing human and horse populations: with precious little surface water in the region, saline groundwater was boiled and condensed for consumption. The woodland was also increasingly consumed for mining infrastructure and to heat the boilers of steam-powered machinery. Although the bush initially seemed endless, timber supplies around Kalgoorlie were running out by the turn of the century. An experienced mine manager estimated the firewood consumption of the Kalgoorlie mines at 47,000 tonnes per month in 1902. In the same year, the Legislative Assembly debated the construction of a $64 \mathrm{~km}$ railway to tap timber reserves to the south. ${ }^{31}$ Before the outbreak of the First World War, the goldfields were served by a vast railway and tram network constructed to enable teams of labourers - many of whom were recent migrants from southern Europe-to extract timber for gold mines. ${ }^{32}$ The extensive deforestation doubtless increased the heat and dust experienced by settlers in Kalgoorlie and its surrounds, reinforcing the dominant image of the region as an arid wilderness. ${ }^{33}$

\footnotetext{
30 C. R. Gosper et al., 'Multi-century periods since fire in an intact woodland landscape favour bird species declining in an adjacent agricultural region', Biological Conservation 230 (2019): 82-90, doi.org/10.1016/ j.biocon.2018.12.011.

31 Cited in Geoffrey Bolton, Spoils and Spoilers: Australians Make Their Environment 1788-1980 (Sydney: George Allen \& Unwin, 1981), 45.

32 The story of the woodlines and their workers is told in Bunbury, Timber for Gold.

33 Andrea Gaynor and Jane Davis, 'People, place and the pipeline: Visions and impacts of the goldfields water supply scheme, 1896-1906', in Water: Histories, Cultures, Ecologies, ed. Marnie Leybourne and Andrea Gaynor (Perth: University of Western Australia Press, 2006), 15-26.
} 


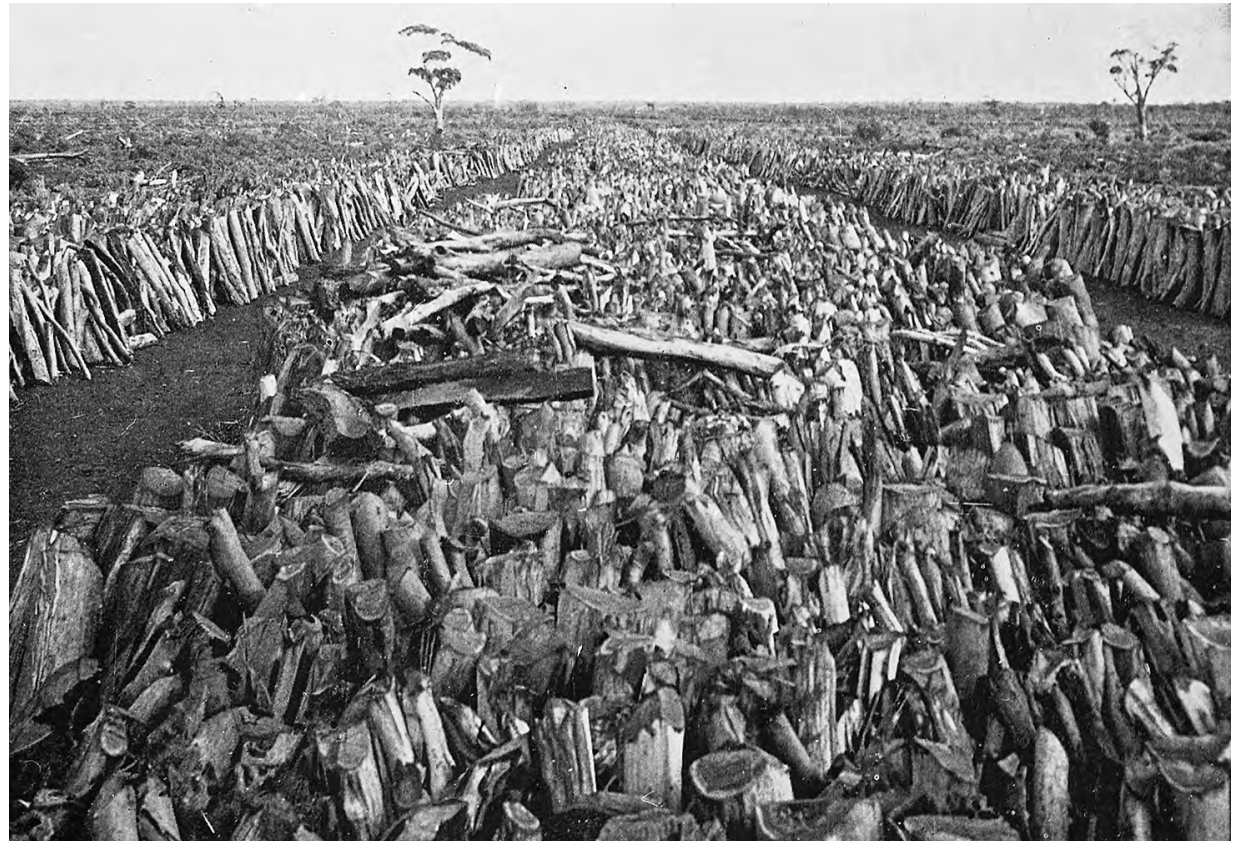

Figure 3: This image, from the head of the Kurrawang woodline, reveals the scale of timber extraction. Eastern Goldfields Historical Society GMWA 74, n.d.

Source: Reproduced with permission from the Eastern Goldfields Historical Society Inc.

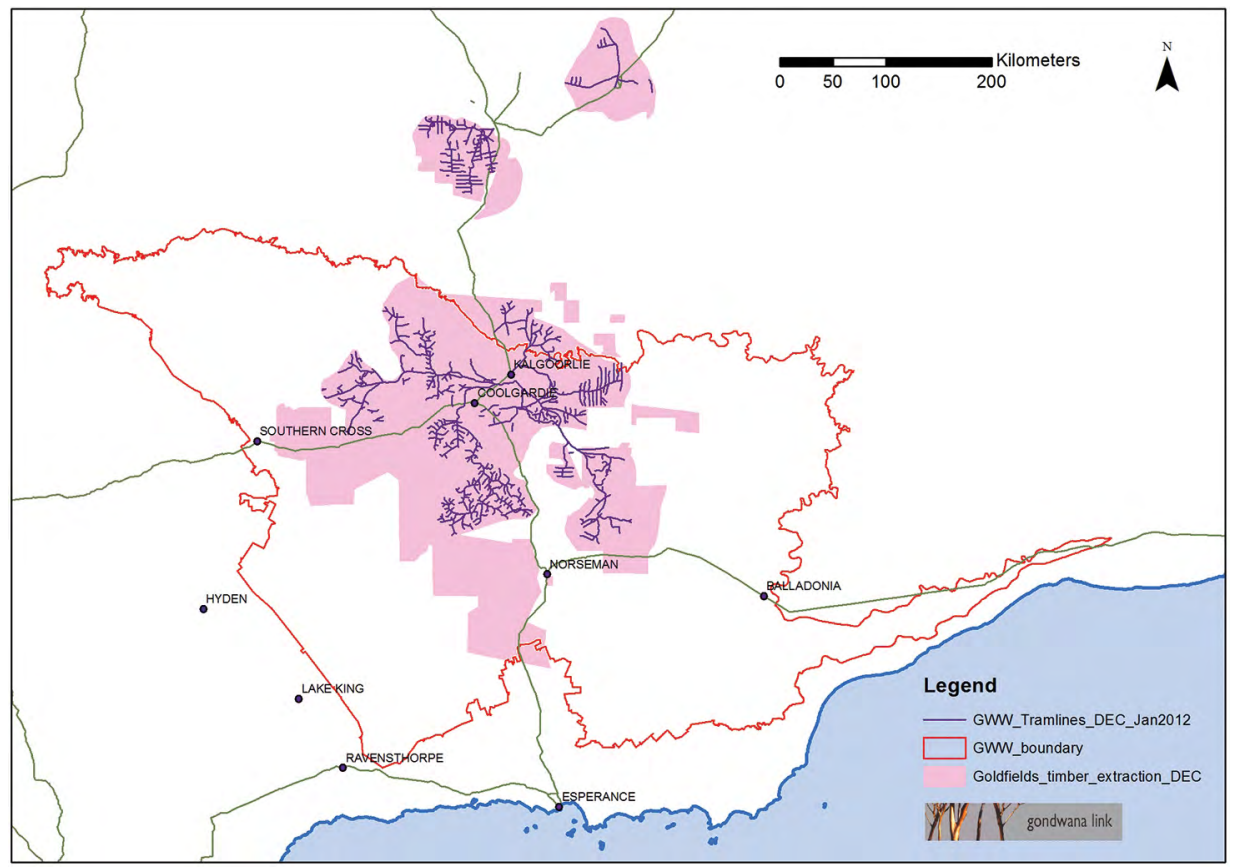

Figure 4: Historical wood-carting tramlines in the GWW area.

Source: Amanda Keesing, Gondwana Link Ltd. 
In 1903, water from the hills near Perth first reached Kalgoorlie via the $540 \mathrm{~km}$ Goldfields Water Supply Scheme. The eight pumping stations along the pipeline were all powered by wood. The pipeline enabled the settler population and its industries to grow in the region with minimal adaptation to local environmental conditions. Water poured through the subterranean network, servicing the city of Kalgoorlie-Boulder along with settlements and agricultural areas along the length of the pipeline. These artificial oases dwarfed the carefully tended water sources on which Aboriginal people had relied for millennia, sustaining an entirely different relation to the region and enabling expansion of the settler population without significant cultural adaptation. Premier Sir John Forrest felt that he had achieved a double victory, praising the engineers at the opening ceremony: 'Not only had they obtained the victory over the opponents of the scheme, but they had won a greater fight and a greater battle - they had conquered the great forces of Nature'. ${ }^{34}$

The historical human-nature relations and interactions in the goldfields were shaped by stories about the place and its economic potential; in turn stories from these settler uses shaped and reinforced wider perceptions of the place, producing particular visions and politics. Without the trees, the viability of settlement and large-scale mining in the region would have been considerably slower and more difficult to achieve, but within pastoral and goldfields stories the woodland figured largely as timber. The story of the water scheme also demonstrates the youth and hubris of a settler society in an unfamiliar place, and reveals the challenges of creating 'home' in what seemed a remote and forbidding place. Decisions on how to deal with nature were made in favour of economic growth and nation-building, but also with the underlying ambition of aligning an alien Australian landscape to the cultural practices of a northern-hemisphere 'home'.$^{35}$ But despite the massive efforts to exploit and conquer the bush, the GWW as a functioning, large-scale ecosystem remains relatively intact and healthy. The trees that once shielded Kalgoorlie from dust storms have grown back. ${ }^{36}$ The woodlands have shown a remarkable resilience to human impact and now stand as a reminder of the native vegetation prior to the nineteenth-century rupture, and what has been lost through land clearing in the adjacent Wheatbelt during the twentieth century. ${ }^{37}$

\footnotetext{
34 Western Australian Museum, 'Building a pipeline', c.2017, museum.wa.gov.au/explore/wa-goldfields/waterarid-land/building-pipeline, accessed 6 June 2021.

35 Gaynor and Davis, 'People, place and the pipeline'.

36 Dust Abatement Technical Sub-Committee, Dust Abatement in the Goldfields of Western Australia: Progress Report for 1973-1981 and Situation Review for the Goldfields Dust Abatement Committee (Perth: Western Australian Department of Conservation and Environment, 1981).

37 Gosper et al., 'Multi-century periods since fire'.
} 


\section{From woodland to farmland}

Where the northern and eastern parts of what is now the GWW became 'storied' as pastoral and mining country, the southern and western parts have been apprehended in relation to an agricultural story. And indeed, agriculture and its infrastructure have come to physically define the GWW on its southern and western boundaries. Where the water pipeline facilitated mining and associated settlement within the woodland, another piece of gigantic infrastructure sought to protect agriculture beyond the woodland, and in the process came to define it.

When the British settler Thomas Austin released 24 rabbits for hunting purposes near Melbourne in 1859, they soon spread, eating out native grassland and impacting both native ecosystems and the wool economy. As the rabbits moved westward, the Western Australian Government responded by building a physical barrier on a massive scale, in a misguided attempt to create a rabbit-free zone in the south-west, where the dream of a vast expanse of wheat farms could flourish. In the nineteenth century, farming had expanded from the early centres of settlement in Western Australia - including the beginnings of what would become the state's 'Wheatbelt'and the vision of a bold yeomanry on the land would be jeopardised by the arrival of rabbits. In 1901 the government commissioned Alfred Canning to survey a fence line; he departed Perth with Hubert Trotman, 'Hassan from Afghanistan' and eight camels. Fences were initially built in three stages between 1901 and 1907; 'Fence No. 1' today marks part of the divide between the wheat-growing country and the southern GWW-a sharp, artificial border that is visible from space. The 'Rabbit Proof Fence' did not keep the rabbits out, but was maintained as a barrier to exclude wildlife such as emus from the farming areas, and was thus re-labelled the 'VerminProof Fence' or 'State Barrier Fence'..$^{38}$ Today it is responsible for regularly killing tens of thousands of migrating emus searching for food and water, and there are concerns at its more general role in disrupting ecological connectivity. ${ }^{39}$

Within the imagined agricultural zone, the land was valued, surveyed and made available for development as farms. In what is today the Western Australian Wheatbelt, only 7 per cent of the vegetation present prior to colonisation remains. ${ }^{40}$ The woodland has had a number of narrow escapes from being converted to yet more farmland. Farms were punched into the western and southern sides of what

38 Alexandra Vlachos, 'Fortress farming in Western Australia? The problematic history of separating native wildlife from agricultural land through the State Barrier Fence', Global Environment 13, no.12 (2020): 368-403, doi.org/10.3197/ge.2020.130206.

39 Keith Bradby et al., 'Ecological connectivity or barrier fence? Critical choices on the agricultural margins of Western Australia', Ecological Management \& Restoration 15, no. 3 (2014): 180-90, doi.org/10.1111/emr.12130. 40 Tony Hughes-d'Aeth, Like Nothing on this Earth: A Literary History of the Wheatbelt (Crawley: UWA Publishing, 2017), 2, based on Environmental Protection of Native Vegetation in Western Australia: Clearing of Native Vegetation, with Particular Reference to the Agricultural Area: Position Statement No. 2 (Perth: Environmental Protection Authority, 1990). 
is now the GWW from the early twentieth century, but the soils and climate were not as favourable as the areas closer to Perth. Indeed, in 1917 there was even a Royal Commission into the likely success of farming in the mallee country in the southern part of the woodland, with doubts arising due to the distance from markets, and salt in the soils. ${ }^{41}$ Another attempt to extend the Wheatbelt, this time using British migrants, faltered and collapsed in the 1930s, largely due to its tenuous economic viability. ${ }^{42}$ In the 1960 s, when huge swathes of public land with mainly light sandy soils were being alienated for private agricultural use, parts of the southern GWW were surveyed into farm blocks; the Western Australian Department of Agriculture also established trial plots within the central western GWW at Forrestania and the Ninety Mile Tank.

A severe drought and the introduction of a wheat quota in 1969 forced a hiatus in further release of crown land for agriculture. This provided an opportunity for a different story about the woodland to take hold in a receptive context. Libby Robin has argued that the period between 1968 and 1973 marked a fundamental change in Australian self-perception. In the eastern states of Australia, these were the early days of popular environmental awareness. ${ }^{43}$ In Western Australia, too, there was greater agitation for conservation, though it struggled to make headway alongside a strong and enduring developmentalism. ${ }^{44}$ Despite having access to the relevant scientific knowledge on salinity and soil erosion risks in the region, Sir Charles Court's coalition government developed a program of further agricultural expansion from 1979, which aimed to turn an additional 2,990,000 ha of habitat over to agriculture. ${ }^{45}$ More than half of the proposed farmland lay within the borders of the GWW. Initially there was little concern expressed over the proposal: key documents were not made public until leaked; many in the farming community wanted more land; and scientists were fearful of repercussions if they spoke out.

\footnotetext{
41 Western Australia, 'Report of the Royal Commission on the Mallee Belt and Esperance Lands', Votes and Proceedings of the Parliament of Western Australia, 1917, paper no. 5, Appendix no. 9.

42 Richard Broome et al., Mallee Country: Land, People, History (Melbourne: Monash University Publishing, 2020), 163.

43 Libby Robin, Defending the Little Desert: The Rise of Ecological Consciousness in Australia (Melbourne: Melbourne University Press, 1998), 134.

44 Lenore Layman, 'Development ideology in Western Australia, 1933-1965', Historical Studies 20, no. 79 (1982): 234-60, doi.org/10.1080/10314618208595682; Quentin Beresford, 'Developmentalism and its environmental legacy: The Western Australia wheatbelt, 1900-1990s', Australian Journal of Politics and History 47, no. 3 (2001): 403-14, doi.org/10.1111/1467-8497.00236; but see also, for example, Keith Bradby, A Park in Perspective: A Report on the Past, Present and Future of Fitzgerald River National Park (Ravensthorpe: Fitzgerald River National Park Association, 1989); Andrea Gaynor, 'State, scientists and citizens: Conserving Lake Magenta and Dragon Rocks, Western Australia', Historical Records of Australian Science 25, no. 2 (2014): 202-16, doi.org/ 10.1071/HR14015.

45 Land Release Policy Review Committee, Rural Land Release Policy in Western Australia, November 1979 (Perth: Premier's Department, 1981), 1.
} 
A small public campaign against the program commenced in 1980 and grew rapidly, at least partly through the efforts of a group of seven concerned citizens, who styled themselves the Land Release Study Group. ${ }^{46}$ Much of the public concern centred on the agricultural suitability of areas in the GWW. One reader of the Countryman wrote of the policy: 'What shocked me was the bland acceptance of the inevitability of compounding our mistakes of the past 100 years by allowing the same farm clearing methods to go forward into the future' ${ }^{47}$ The Labor government elected in 1983 established a moratorium on releases while further investigations were conducted, both into agricultural suitability and the presence of rare species in areas subject to allocation proposals. While the new government did not completely abandon the vision of turning more bush into agricultural land, the immediate threat to the woodlands was gone and the small group of conservationists refocused on other priorities.

\section{New connections}

Where the old stories from the region had connected it to markets-for gold, wool and wheat-new stories emphasised different forms of connectivity. In 1989, an international conference in Western Australia on 'The role of corridors' brought together some key thinking on the importance of island biogeographical principles and the need for ecological connectivity. ${ }^{48}$ Application of island biogeographical principles by Western Australian Museum researchers in the early 1980s had already painted a bleak future for the small unconnected nature reserves dotted through the Western Australian Wheatbelt. ${ }^{49}$ At the 1989 conference the need and potential for ecological connectivity at all scales was emphasised. Keith Bradby, who had been a key member of the Land Release Study Group, described the potential for community-based conservation work already under way to greatly increase ecological permeability and connectivity between the wet forests and the more arid interior of

46 Australian Conservation Foundation, Diversity or Dust: A Review of the Impact of Agricultural Land Clearance Programmes in South West Australia (Melbourne: Australian Conservation Foundation, 1984).

47 M. Rogers of Wongan Hills, 'Farm clearing errors go on' [letter to the editor], Countryman, 13 November 1980.

48 D. A. Saunders and R. J. Hobbs, Nature Conservation 2: The Role of Corridors (Chipping Norton, NSW: Surrey Beaty \& Sons, 1991). The term 'landscape connectivity' describes the ways and degree of species and genetic movement among resource patches within a given landscape as well as the human perception of connectedness of patterns of vegetation cover within a landscape. While large-scale connectivity conservation has been discussed since the 1970s, it remained a controversial approach within the scientific conservation biology community until the early twenty-first century, when significant contributions were made to the field.

49 D. J. Kitchener et al., 'The conservation value for mammals of reserves in the Western Australian wheatbelt', Biological Conservation 18 (1980): 179-207, doi.org/10.1016/0006-3207(80)90033-6; D. J. Kitchener et al., 'Birds in Western Australian wheatbelt reserves—implications for conservation', Biological Conservation 22 (1982): 127-63, doi.org/10.1016/0006-3207(82)90010-6; D. J. Kitchener et al., 'Lizard assemblage and reserve size and structure in the Western Australian wheatbelt-some implications for conservation', Biological Conservation 17 (1980): 25-62, doi.org/10.1016/0006-3207(80)90024-5. 
Australia. ${ }^{50}$ Informal discussions on these concepts and their potential application in Western Australia continued for over a decade, until the idea of co-ordinating and facilitating the work of conservation groups to achieve greater ecological (and social) connectivity consolidated at the turn of the millennia. Funds from an anonymous American donor, sourced through the Nature Conservancy, together with matching funds from The Wilderness Society (TWS) and Greening Australia enabled establishment of the Gondwana Link program in 2002. The Friends of Fitzgerald River National Park, the Fitzgerald Biosphere Group, the Malleefowl Preservation Group and the Australian Bush Heritage Fund also joined the initiative. Bradby became its co-ordinator and within the first year the same American donor financed a 'Spark Fund' to support initial on-ground operations by the groups involved. This was a period of increasing ambition amongst Australian NGOs, typified by TWS's 'Wild Country' program, which brought together eminent scientists to formulate a national approach to restoring key ecological functions. ${ }^{51}$ It was the right time to turn big thinking and bold visions into action.

From its inception, Gondwana Link projected the vision of a link all the way from the wet forests of the far south-west through the goldfields woodlands to the red heart of Australia. The link did not end at connecting places; it also proclaimed the importance of connecting people and their stories. But the goldfields woodlands were little known and inconspicuous in spite of their vastness: first steps therefore included the mapping, naming and promoting of the 'bush beyond the fence'.

In 2006, the TWS scientist Simon Judd, who functioned as the Science Council co-ordinator for Gondwana Link from 2003, drew the boundaries on a map, defining what was later labelled the 'Great Western Woodlands'. Using the agricultural clearing line along the State Barrier Fence, the Coolgardie bioregion, and the MulgaEucalypt line $e^{52}$ that marks the division between the Mediterranean climate of the south-west and the arid zone of the north-east, Judd connected a myriad of scientific data to give an old living place a new identity and visibility to people outside the region..$^{53}$ While both the Mulga-Eucalypt line and the State Barrier Fence more or less follow a historical rainfall line, the act of mapping is never innocent or 'natural': maps represent more than space and allow territories to be imagined in particular ways and facilitate acceptance of that vision. ${ }^{34}$ The aim was to push the woodlands

\footnotetext{
50 Keith Bradby, 'Data is never enough - the local approach to landcare', in The Role of Corridors, ed. Dennis Saunders and Richard Hobbs (Chipping Norton, NSW: Surrey Beatty and Sons, 1991), 377-85.

51 The Wilderness Society, Wild Country: A New Vision for Nature (Canberra: The Wilderness Society, 2005).

52 The botanist Ferdinand von Mueller had first introduced the Mulga Line in 1883. Geographers and fellow botanists, including F. I. Woodward, Ludwig Diels, E. de C. Clarke, Charles Gardner, N. T. Burbidge and J. S. Beard, have further refined and mapped the Mulga-Eucalypt line.

53 Simon Judd, personal communication with the authors, November 2018.

54 Graeme Wynn, 'Science in action', foreword to Stéphane Castonguay, The Government of Natural Resources: Science, Territory, and State Power in Quebec, 1867-1939, translated by Käthe Roth (Vancouver: UBC Press, 2020), xix.
} 
into the minds of settler Australians, who seemed largely unaware of its existence, and to highlight both its size and integrity. Once captured on a Cartesian map, the bush was in need of a better name. Because it lacked a single Aboriginal name, priority was given to a name the majority of Australian society could relate to, and the 'Great Western Woodlands' emerged over other suggestions.

Scholars in the fields of geopolitics and human geography remind us that power, control and Foucault's dispositif all play into the act of place-naming. ${ }^{55}$ Despite Gondwana Link's collaboration with, and its commitment to, the Ngadju People, the conservationists created once again a colonial name in English, with the imperial word 'Great' and the geopolitical word 'Western'. The notion of 'Great' bears similarities with a series of other 'Great' Australian places ('Great Otway Park', 'Greater Alpine National Parks', 'Greater Wellington National Park', the 'Great Dividing Range' and so on), and the word 'Western', intended or not, is more than a reference to a cardinal direction. By choosing the name 'Great Western Woodlands', a chance was lost to accommodate and foreground Indigenous knowledge of the area, ${ }^{56}$ or to narrate that knowledge and tradition into the new name of the place. Yet the Ngadju People who hold Native Title over much of the south-eastern GWW recognise the term's utility, and use it in public descriptions of their Country. ${ }^{57}$

Judd worked with Alexander Watson and others from TWS to target a broader public audience and raise awareness of this remote and low-profile piece of bush with the publication The Extraordinary Nature of the Great Western Woodlands. ${ }^{58}$ Lavishly illustrated with appealing photographs of GWW plants, animals, landscapes and people alongside lively thematic text contributed by expert authors, the booklet 'storied' the GWW for a government and wider audience. Together with a carefully planned communication and lobbying effort led by TWS, it led directly to a government commitment of $\mathrm{A} \$ 3.8$ million for protection and management of the GWW. ${ }^{59}$ The government planner Ian Herford recalls that he relied on Watson's

55 For example, Frédéric Giraut and Myriam Houssay-Holzschuch, 'Place naming as dispositif: Toward a theoretical framework', Geopolitics, 21, no. 1 (2016): 1-21, doi.org/10.1080/14650045.2015.1134493. In 1977, Yi-Fu Tuan argued that a place differs from space by the human invest of naming and meaning: Y.-F. Tuan, Space and Place: The Perspective of Experience (Minneapolis: University of Minnesota Press, 1977).

56 In a South American example, Sébastien Boillat, Elvira Serrano, Stephan Rist and Fikret Berkes show how indigenous and Western place-naming dramatically differs, and how Indigenous place names can identify natural dangers, spirits or game as well as carrying worldviews, knowledge, spirituality and dynamic human-nature relations. They also point to the fact that indigenous peoples, in this example the comunarios, consider places as living beings and thus the option that places may pre-exist human knowledge: Sébastien Boillat et al., 'The importance of place names in the search for ecosystem-like concepts in indigenous societies: An example from the Bolivian Andes', Environmental Management 51 (2013): 663-78, doi.org/10.1007/s00267-012-9969-4.

57 See for example Ngadju Conservation, 'Ngadju Rangers', Norseman, 2021, ngadjuconservation.org/rangers; 'About us', Ngadju Conservation, Norseman, 2021, ngadjuconservation.org/about-us, accessed 6 June 2021.

58 Watson, The Extraordinary Nature.

59 'Minister releases vision for Great Western Woodlands', Government of Western Australia Media Statements, 3 November 2010, www.mediastatements.wa.gov.au/Pages/Barnett/2010/11/Minister-releases-vision-for-the-GreatWestern-Woodlands.aspx, accessed 6 June 2021. 
work when he was compiling A Biodiversity and Cultural Conservation Strategy for the Great Western Woodlands in 2010 as part of that commitment. ${ }^{60}$ Herford remembers the difficult years of planning and bringing stakeholders with very different views and interests together. But what made the case of the GWW unique, in his long experience, was the nature of its establishment: 'The whole birth of it was really quite interesting ... [it was the] only case of its kind, that I ever worked with, basically, where a bunch of intelligent ... people brought into being something which previously didn't exist'. ${ }^{61}$ Gondwana Link appointed Peter Price GWW project manager in 2010.

The philosopher Richard Day argues that disappointment with official institutions and their inaction is the main driver for new social networks to appear and existing ones to expand. ${ }^{62}$ A network of local actors, conservation groups and Indigenous people became the leading force for establishing, promoting and managing the GWW, but it was a rough path and a range of different views, challenges and questions arose along the way. For one, the government's commitment included the A $\$ 3.8$ million, but no tenure change, which was, according to most conservation groups, crucial to the better management and protection of the GWW. There were also competing stories about the nature of conservation and how it could best be achieved; these had to be reconciled for collective action to proceed. For example, views on the impact of mining and mining infrastructure, as well as the best use of mining offsets and bonds, were formed counter to the dominant narrative that mining and conservation interests were irreconcilable. All stakeholders agreed on fire management as a major problem, but strategies for preventing wildfires diverged and were hotly discussed. Not all stakeholders accepted the stronger involvement of Aboriginal groups or the changes needed to recognise and respect existing and potential Native Title interests. Finally, Gondwana Link's focus remained on the big picture and a conservation story - that the country needs caring people—at once new and very old. Its large-scale, multi-use conservation approach fitted neither the more rigid demands of some of the larger conservation groups nor the minimalist 'priority thinking' with regard to biodiversity (priority ecological communities and species, for example) of some scientists and government officials.

Dissatisfaction with the constrained government planning process, the expenditure of considerable funds on destructive fire management practices, and the focus on rare species and the formal conservation estate, rather than the needs of the larger GWW, grew after release of the formal government strategy. In 2011 a planning review

60 Western Australian Department of Environment and Conservation, A Biodiversity and Cultural Conservation Strategy for the Great Western Woodlands (Perth: The Department, 2010).

61 Personal conversation with Alexandra Vlachos, November 2018.

62 Richard Day, 'Ethics, affinity and the coming communities', Philosophy and Social Criticism 27, 1 (2001): 21-38, doi.org/10.1177/019145370102700102, and Lejano et al., The Power of Narrative in Environmental Networks, 4. 
was conducted. Funded by a mining company and organised by the conservation interests, it involved a wide range of private sector stakeholders. This process led to a more discrete series of local Conservation Action Plans being developed, in conjunction with implementation programs, underpinned by a recognition that the larger GWW is in fact made up of a number of smaller areas where effective social and management networks function. ${ }^{63}$ Foremost amongst these were areas where local government was keen to have greater involvement, as well as traditional owners. Gondwana Link had become more organisationally involved, and the Pew Charitable Trusts were also becoming more involved in supporting GWW work. Building on the bonds established with the Schultz family, Les Schultz and Peter Price, Ngadju people based in Norseman, became the leading actors in establishing the Ngadju Ranger Program in 2013. This commenced shortly before the longrunning Ngadju Native Title claim was recognised by the Federal Court, with Exclusive Native Title granted in 2014 (and extended over a wider area in 2017). Gondwana Link maintained strong bonds with a variety of stakeholders, including some active in the mining industry, and drew in additional support. The Nature Conservancy worked with Gondwana Link to secure funding from the Thomas Foundation for BirdLife Australia to commence detailed studies of bird populations and movement across the GWW. ${ }^{64}$

By this stage a number of other scientists were conducting research in the area, ${ }^{65}$ and specific conservation issues were being debated at state level. Foremost amongst these was the long-standing debate over the mining of banded ironstone formations - low, rugged ranges, mainly in the northern sections of the GWW. One major success, involving groups such as the Wildflower Society, TWS and BirdLife Western Australia, saw protection from mining of the Helena and Aurora Range (Bungalbin, north-western GWW), achieving a milestone when the McGowan Labor Government vowed in December 2017 to give the ranges the highest available level of conservation protection. ${ }^{66}$ Another major threat to the area, the southern Shire of Esperance's 2014 proposal to have some 500,000 ha of GWW land cleared for agriculture, had a short lifespan once the plans became public.

63 Ironbark Environmental, Towards a Land Use Plan for the Great Western Woodlands, Stage One: Scoping Study, Main Report and Summary Document, A Report to the Woodlands Initiative (Albany: Ironbark Environmental, 2011). 64 K. Bradby, J. O'Connor and J. Fitzsimons, 'The Great Western Woodlands: An introduction to the last, vast temperate woodland on Earth', Wingspan 21, no. 1 (2011): 16-17, 19.

65 Prominent among others stands CSIRO scientist Suzanne Prober, who has widely published on the GWW, including on Aboriginal fire management in collaboration with Ngadju elders: S. N. Prober et al., 'Ngadju kala: Australian Aboriginal fire knowledge in the Great Western Woodlands', Austral Ecology, 41 (2016): 716-32, doi. org/10.1111/aec.12377. Prober also leads the Great Western Woodlands SuperSite, a long-term ecological research site of the Terrestrial Ecosystems Research Network (TERN): supersites.tern.org.au/supersites/gwwl, accessed 6 June 2021.

66 'State Government preserves unique Helena-Aurora Range', Western Australian Government media statement, 21 December 2017, www.mediastatements.wa.gov.au/Pages/McGowan/2017/12/State-Governmentpreserves-unique-Helena-Aurora-Range.aspx, accessed 6 June 2021. 
The new narrative about the woodland began to take root and the 'GWW' designation is now widely used in the scientific community, the media and tourist brochures. Mapping and naming were instrumental in challenging established thinking and shifting public attitudes. Another fundamental shift was the idea of connectivity, giving the GWW a larger meaning in the context of biodiversity conservation in south-western Australia. A decade is a short time in which to establish a new label, and while not everyone is equally happy with the designation, it stimulated new ideas and increased awareness of the area and its many values. Moreover, by 2019, key actors such as Price were increasingly emphasising the need for the woodlands to become more strongly recognised and branded as Aboriginal land. ${ }^{67}$

\section{Conclusion}

The deeply artificial landscape of the Wheatbelt and the prospect of opening up more land for marginal agriculture in what is one of the world's most important biodiversity hotspots brought the woodlands to environmentalist attention and stimulated the process by which an identity was assigned to the 'bush beyond the fence'. In a broader historical context, what had to be achieved was a settler society recognising value in places beyond the old resource-oriented frameworks. Commitment to place and 'storying' its ecological and social diversity had a gamechanging impact in successfully relabelling the area as 'GWW'. Gondwana Link and key collaborators actively included the traditional owners and were mindful of local actors, including those involved in the mining industry. Seeking broad collaborations with national and international environmental groups and maintaining ties to dedicated scientists and sympathetic government actors required Gondwana Link to maintain a complex narrative network, in contrast to a simpler one that is built on binaries such as nature v. culture or wilderness v. resource extraction.

Promoting and managing the GWW is an ongoing process and currently relies on a broad network of allies, international funding and a group of key local actors devoted to the country. Bradby insists: 'I fervently believe that the "glue" which holds together large-scale landscape management is the country and the people who care deeply for that country. ${ }^{\prime} 8$ New stories about local places can help to generate perspectives more congruent with ecological resilience than can older, resourceoriented narratives. It is not easy to deliberately develop and release a new story about a place; even in a favourable context, considerable work may be required for the story to propagate, and older stories will often endure. But the example of the Great Western Woodlands demonstrates that narrative shift, along with other forms of environmental action, can produce material change.

67 Personal communication with Alexandra Vlachos, April 2019.

68 Bradby, 'Woodlands', 314. 
This text is taken from International Review of Environmental History, Volume 7 , Issue 2, 2021, edited by James Beattie, published 2021 by ANU Press,

The Australian National University, Canberra, Australia.

doi.org/10.22459/IREH.07.02.2021.05 